\title{
PARACERVICAL BLOCK ANAESTHESIA IN LABOUR
}

\author{
IAN G. L. VAN PraAGh, M.D., F.R.C.s.(c), F.A.C.s., \\ F.A.C.O.G., M.R.C.O.G., AND W. G. POVEY, M.D. ${ }^{*}$
}

THE SIMPLICITY AND SAFETY of the paracervical block for the relief of the discomfort of the first stage of labour has been noted by several authors in recent years. ${ }^{1-0}$ Concurrently but rarely, significant complications have been reported.1, 6, 6, 8, 10, 11 Despite favourable European reports appearing since $1926,{ }^{12-14}$ no American report appeared on the paracervical block until that of Rosenfeld in $1945 .^{16}$

It was proposed to evaluate further the efficacy and safety of the paracervical block as a method of analgesia in the first stage of labour in uncomplicated pregnancy. ${ }^{16}$ This simple technique, easily perfected by a physician without special training in anaesthesiology, was assessed as an alternative to more sophisticated conduction methods that demand special training and experience. It was hoped that the technique would decrease the use of centrally acting analgesics which may cause neonatal depression. ${ }^{17}$ The relatively brief duration of action and the ineffectiveness in achieving adequate second-stage analgesia were recognized.11 These factors were not considered contraindications to its use.

The neuroanatomic basis for the paracervical block, which is generally agreed upon, ${ }^{18-21}$ has previously been described. ${ }^{10}$ The paracervical anaesthesia blocks both sympathetic and parasympathetic nerve fibres entering the uterosacral ligaments at the base of the broad ligaments. It is ineffective in relieving secondstage discomfort because the pain of the second stage is due primarily to distension of the lower birth canal, vulva, and perineum, which is largely innervated by the sensory fibres of the pudendal nerves which enter the spinal cord through the posterior sacral roots $\left(\hat{S}_{2,8,4}\right)$.

\section{INDICATIONS}

Paracervical blocks were used in primiparae and multiparae during the first stage of labour in full-term normal pregnancies presenting by the vertex. Contraindications included abnormal antepartum bleeding, malpresentation, foetal distress, infection, and a history suggestive of sensitivity to local anaesthetic agents.

\section{METHOD}

The blocks were administered to parturients in established labour at cervical dilations of 2 to $8 \mathrm{~cm}$. Occasionally a second block was used if the effect of the first had disappeared before the onset of the second stage of labour.

Our technique, which has been previously described, ${ }^{16}$ involved the accurate

'Woman's Hospital, St. Luke's Hospital Center, 114th Street \& Amsterdam Avenue, New York, N.Y. Dr. Povey's present address is: Population Council, Ford Foundation, 60 Av. Mohamed V, Tunis, Tunisia. 
placement of 10 to $12 \mathrm{ml}$. of 1 per cent mepivicaine hydrochloride (Carbocaine) ${ }^{\circ}$ in each lateral vaginal fornix at 3 to 4 o'clock and 8 to 9 o'clock at a depth of 6 to $12 \mathrm{~mm}$. An equal number of blocks were done using Kobak's needlef and the simple device described by Povey.22 Although some authors have recommended paracervical injection at a depth of 1.5 to $2.5 \mathrm{~cm} .{ }^{2,18,28}$ we found, as did Davis et al., that more superficial injection gave excellent analgesia and minimized the risk of puncturing blood vessels. Slow injection of the agent with intermittent aspiration was practised. After one side of the block was placed, one uterine contraction was observed, along with a check of maternal pulse, blood pressure, and foetal heart rate, before the second side was done.

Of the 208 primiparae, 172 were delivered under general anaesthesia, 35 under conduction anaesthesia, and one received nothing. Thirty-one primiparae delivered spontaneously, while 157 were delivered by low forceps, 13 by mid-forceps, and 7 by caesarean section. Of the 169 multiparae, 120 were delivered under general anaesthesia, 36 under conduction anaesthesia and 13 received nothing. Fifty-one multiparae were delivered spontaneously, 112 by low forceps, three by midforceps and three by caesarean section.

\section{Results}

Paracervical block anaesthesia was administered to 377 patients in the first stage of labour: 208 were primiparae and 169 were multiparae (Table I). In 18

TABLE I

Patient Population

\begin{tabular}{ccc}
\hline \hline Age (years) & Primiparae & Multiparae* \\
\hline$<15$ & 2 & 0 \\
$15-20$ & 59 & 20 \\
$21-30$ & 122 & 102 \\
$31-40$ & 23 & 44 \\
$>40$ & 2 & 3 \\
Total & 208 & 169 \\
\hline
\end{tabular}

*Parity of the 169 multiparae:

$\begin{array}{lr}p \text { i to iii } & 139 \\ p \text { iv to vi } & 20 \\ p>\text { vi } & 10\end{array}$

of the primiparae and 12 of the multiparae, a second block was done, 30 to 90 minutes after the first. The duration of each stage of labour (Table II) was within the normal range for both primiparae and multiparae.24, ${ }^{25}$ The paracervical block therefore did not alter the length of labour. Since the blocks were used in a "single shot" technique, other medications were used in 81 per cent of the primiparae and 68 per cent of the multiparae to achieve acceptable analgesia throughout the first stage of labour (Table III).

In 336 cases, the membranes were ruptured at the time of the administration

-Winthrop Laboratories, New York.

tV. Mueller \& Company, Chicago. 
TABLE II

LENGTH OF LABOUR

\begin{tabular}{cccc}
\hline \hline Stage & Duration & Primiparae & Multiparae \\
\hline First & $<2$ hours & 0 & 1 \\
& $2-4$ & 10 & 25 \\
& $5-8$ & 55 & 71 \\
& $9-12$ & 72 & 46 \\
& $13-16$ & 47 & 18 \\
& $>16$ & 24 & 8 \\
Second & $0-30$ min. & 45 & 79 \\
& $31-60$ & 95 & 69 \\
& $61-90$ & 46 & 17 \\
& $>90$ & 22 & 4 \\
Third & $0-30$ min. & 208 & 154 \\
& $>31$ & 0 & 15 \\
\hline
\end{tabular}

TABLE III

Other Medicatron Used

\begin{tabular}{|c|c|c|c|c|c|}
\hline & Meperidine & Promethazine & Atropine & Other & None \\
\hline $\begin{array}{l}\text { Primiparae } \\
\text { Before paracervical block } \\
\text { After paracervical block }\end{array}$ & $\begin{array}{l}96 \\
90\end{array}$ & $\begin{array}{l}93 \\
33\end{array}$ & $\begin{array}{l}20 \\
39\end{array}$ & $\begin{array}{r}29 \\
8\end{array}$ & $\begin{array}{l}39 \\
77\end{array}$ \\
\hline $\begin{array}{l}\text { Multiparae } \\
\text { Before paracervical block } \\
\text { After paracervical block }\end{array}$ & $\begin{array}{l}85 \\
54\end{array}$ & $\begin{array}{l}71 \\
16\end{array}$ & $\begin{array}{l}39 \\
32\end{array}$ & $\begin{array}{l}22 \\
11\end{array}$ & $\begin{array}{l}33 \\
88\end{array}$ \\
\hline
\end{tabular}

of the block (Table IV). In 87 per cent the cervical dilation was between 4 and $8 \mathrm{~cm}$. In one case, there appeared to be a transient decrease in the frequency and intensity of uterine contractions following the block. The rate of cervical dilation was not accelerated following the block as had been suggested by others.1, 2, 18, 19 These findings are similar to those of Zourlas and Kumar who used objective techniques to measure uterine work. ${ }^{26}$ The maternal blood pressure largely remained unaltered. Transient post-block foetal bradycardia of below 100 was noted in 4 patients (1.6\%). Of the 31 instances of foetal tachycardia, only 3 appeared after the block.

Table V shows that 85 per cent of the blocks in the primiparae lasted 31 to 120 minutes and 5 per cent lasted over 120 minutes. In the multiparae 89 per cent lasted 31 to 120 minutes and 1 per cent lasted over 120 minutes. The results (Table VI) were good in 81 per cent of the primiparae, fair in 14 per cent, poor in 3 per cent and undecided in 2 per cent. In the multiparae, the results were good in 76 per cent, fair in 17 per cent, poor in 5 per cent and undecided in 2 per cent.

Poor results were due to inaccurate placement of the block, owing to inexperience in the physician or lack of co-operation in the patient. Blood aspiration, which occurred during the placement of eight blocks, resulted from the needle's being directed too far laterally in the vaginal fornix. It did not occur when using Povey's needles and only occurred when the Kobak needle protruded to its full length of $12 \mathrm{~mm}$.

There were no significant maternal complications. Other reports have men- 
TABLE IV

Maternal and Foetal Status

\begin{tabular}{|c|c|c|c|c|}
\hline & \multicolumn{2}{|c|}{ Primiparae } & \multicolumn{2}{|c|}{ Multiparae } \\
\hline & at block & after block & at block & after block \\
\hline $\begin{array}{l}\text { Membranes } \\
\text { intact } \\
\text { ruptured }\end{array}$ & $\begin{array}{r}31 \\
177\end{array}$ & $\begin{array}{r}12 \\
196\end{array}$ & $\begin{array}{r}8 \\
161\end{array}$ & $\begin{array}{r}0 \\
169\end{array}$ \\
\hline $\begin{array}{l}\text { Dilation of } \\
\mathbf{2} \\
\mathbf{3} \\
4 \\
\mathbf{5} \\
\mathbf{6} \\
\mathbf{7} \\
\mathbf{8}\end{array}$ & $\begin{array}{r}5 \\
15 \\
46 \\
57 \\
38 \\
36 \\
11\end{array}$ & $\begin{array}{r}2 \\
15 \\
36 \\
48 \\
45 \\
39 \\
23\end{array}$ & $\begin{array}{r}3 \\
13 \\
32 \\
47 \\
50 \\
16 \\
8\end{array}$ & $\begin{array}{r}3 \\
14 \\
27 \\
41 \\
50 \\
23 \\
11\end{array}$ \\
\hline $\begin{array}{l}\text { Frequency } \\
\text { contrac } \\
2 \\
3 \\
4 \\
5 \\
6 \\
7 \\
8 \\
9\end{array}$ & $\begin{array}{r}22 \\
120 \\
34 \\
21 \\
4 \\
2 \\
1 \\
4\end{array}$ & $\begin{array}{r}27 \\
125 \\
28 \\
14 \\
7 \\
2 \\
2 \\
3\end{array}$ & $\begin{array}{r}28 \\
98 \\
27 \\
14 \\
1 \\
1 \\
0 \\
0\end{array}$ & $\begin{array}{r}28 \\
88 \\
32 \\
12 \\
9 \\
1 \\
0 \\
0\end{array}$ \\
\hline $\begin{array}{l}\text { Maternal bl } \\
\text { up } \\
\text { normal } \\
\text { down }\end{array}$ & $\begin{array}{r}7 \\
200 \\
1\end{array}$ & $\begin{array}{r}14 \\
193 \\
1\end{array}$ & $\begin{array}{r}3 \\
73 \\
93\end{array}$ & $\begin{array}{r}3 \\
70 \\
96\end{array}$ \\
\hline $\begin{array}{c}\text { Foetal hear } \\
<100 \\
100-130 \\
131-150 \\
>150\end{array}$ & $\begin{array}{r}2 \\
14 \\
173 \\
19\end{array}$ & $\begin{array}{r}5 \\
17 \\
164 \\
22\end{array}$ & $\begin{array}{r}1 \\
10 \\
146 \\
12\end{array}$ & $\begin{array}{r}2 \\
13 \\
142 \\
12\end{array}$ \\
\hline
\end{tabular}

TABLE V

\begin{tabular}{lcc}
\hline \hline & Primiparae & Multiparae \\
\hline Duration of block (min.) & & \\
0 & 2 & 5 \\
$1-30$ & 18 & 9 \\
$31-60$ & 56 & 79 \\
$61-90$ & 82 & 50 \\
$91-120$ & 39 & 23 \\
$>120$ & 11 & 3 \\
Block to delivery time (min.) & & \\
$0-61$ & 29 & 41 \\
$61-120$ & 91 & 78 \\
$121-180$ & 56 & 27 \\
$>180$ & 32 & 23 \\
\hline
\end{tabular}

tioned peripheral vascular collapse, sacral neuritis, ${ }^{6}$ convulsions, ${ }^{6}$ and broad ligament haematomas. ${ }^{8}$ No complications followed the eight blocks in which blood was aspirated. There was no postpartum morbidity. Early in the series there were four patients who felt faint after rapid injection of the anaesthetic solution. There 
TABLE VI

RESULTS

\begin{tabular}{lcccc}
\hline \hline & Good & Fair & Poor & Difference of opinion \\
\hline Primiparae & 170 & 27 & 7 & 4 \\
Multiparae & 129 & 28 & 9 & 3 \\
\hline
\end{tabular}

were no significant alterations in pulse or blood pressure. Twelve patients experienced numbness or tingling in one or both legs that spontaneously disappeared within 15 minutes.

Adrenaline was not used to prolong the effect of the block ${ }^{27}$ because of the possibility of inducing uterine inertia. ${ }^{28}$

\section{Condition of the Neonates}

Ninety per cent of the infants (336) were in good condition at birth. The 39 infants (10\%) with low one-minute Apgar scores ${ }^{29}$ were of particular interest (Table VII). Twenty-seven were born to primiparae and 12 to multiparae. There was one with Apgar 1, four with Apgar 2, eleven with Apgar 3, nine with Apgar 4, four with Apgar 5, and ten with Apgar 6. Good results, in terms of adequate analgesia, were noted in 29 cases, six were fair, and four were poor. The average duration of action of the block was 83 minutes. There were three instances of transient foetal bradycardia. Significant postmaturity was present in the neonate of one primipara in which the post block foetal heart rate dropped to below 100. Thirty-eight of the 39 infants had good five-minute Apgar scores ( 8 to 10). There was partial abruptio placentae in the case of one infant who remained depressed at five minutes of age.

An attempt was made to assess the low one-minute Apgar scores. There was no explanation in 28 cases. Of the other 11 depressed neonates one or more of the following factors were noted: four cases of cephalopelvic disproportion, including two difficult mid-pelvic forcep operations, two congenital heart problems, two cord problems and one abruptio placentae, one severe postmature infant, and at least one anaesthesia problem. Possibly more of these low scores were attributable to general anaesthesia; this could only be corroborated by accurate neonatal acid-base studies. There was no clinical evidence that the use of paracervical block during labour was responsible for any of the low Apgar scores. There was no foetal mortality or significant foetal morbidity. The transient post-block foetal bradycardia (Table VIII) did not indicate foetal distress, and in only one instance was it subsequently related to a low Apgar score, secondary to postmaturity rather than to the block itself. The cause of post-block foetal bradycardia is not clear. We agree with Davis et al.4, 18 that it does not represent foetal distress but must be differentiated from it. This difficult clinical problem can only be clarified by continuous careful clinical observation and possibly by obtaining acid-base values of blood taken from the foetal scalp during labour. ${ }^{30}$ It may be due to one of several factors, including vaginal manipulation, 
TABLE VII

Survey of 39 Infants with Low ApGar Scores

\begin{tabular}{|c|c|c|c|}
\hline & 27 Primiparae & 12 Multiparae & 39 Total \\
\hline $\begin{array}{l}\text { Apgar scores } \\
1 \\
2 \\
3 \\
4 \\
5 \\
6\end{array}$ & $\begin{array}{r}0 \\
3 \\
10 \\
5 \\
3 \\
6\end{array}$ & $\begin{array}{l}1 \\
1 \\
1 \\
4 \\
1 \\
4\end{array}$ & \\
\hline $\begin{array}{l}\text { Block result } \\
\text { good } \\
\text { fair } \\
\text { poor } \\
\text { Average block duration (min.) }\end{array}$ & $\begin{array}{r}22 \\
4 \\
1 \\
85\end{array}$ & $\begin{array}{r}7 \\
2 \\
3 \\
61\end{array}$ & $\begin{array}{r}29 \\
6 \\
4 \\
83\end{array}$ \\
\hline $\begin{array}{l}\text { Foetal heart after block } \\
\text { constant } \\
\text { decreased but }>100 \\
<100\end{array}$ & $\begin{array}{r}25 \\
1 \\
1\end{array}$ & $\begin{array}{r}11 \\
1 \\
0\end{array}$ & $\begin{array}{r}36 \\
2 \\
1\end{array}$ \\
\hline $\begin{array}{l}\text { Post-block anaesthesia } \\
\text { yes } \\
\text { no }\end{array}$ & 16 & $\begin{array}{l}7 \\
5\end{array}$ & $\begin{array}{l}23 \\
16\end{array}$ \\
\hline $\begin{array}{l}\text { Delivery anaesthesia } \\
\text { general } \\
\text { pudendal }\end{array}$ & 24 & $\begin{array}{l}5 \\
8 \\
4\end{array}$ & $\begin{array}{r}16 \\
32 \\
7\end{array}$ \\
\hline $\begin{array}{l}\text { Delivery method } \\
\text { low forceps } \\
\text { mid-forceps } \\
\text { caesarean } \\
\text { spontaneous } \\
\text { Condition of infant five minutes } \\
\text { postpartum }\end{array}$ & $\begin{array}{r}20 \\
\mathbf{3} \\
\mathbf{3} \\
\mathbf{1}\end{array}$ & $\begin{array}{l}8 \\
0 \\
1 \\
3\end{array}$ & $\begin{array}{r}28 \\
3 \\
4 \\
4\end{array}$ \\
\hline $\begin{array}{l}\text { good } \\
\text { fair } \\
\text { dead }\end{array}$ & $\begin{array}{r}26 \\
1 \\
0\end{array}$ & $\begin{array}{r}12 \\
0 \\
0\end{array}$ & $\begin{array}{r}38 \\
1 \\
0\end{array}$ \\
\hline $\begin{array}{l}\text { Explanation of low Apgar scores } \\
\text { none } \\
\text { due to paracervical block } \\
\text { due to delivery anaesthesia } \\
\text { foetal cause } \\
\text { cord cause } \\
\text { placental abnormality } \\
\text { other }\end{array}$ & $\begin{array}{c}18 \\
0 \\
1 \\
\text { CPD 3, postmat. 1 } \\
2 \\
\text { partial abruptio 1 } \\
\text { difficult } \\
\text { mid-forceps 2 } \\
\text { congenital } \\
\text { heart disease 1 }\end{array}$ & $\begin{array}{c}10 \\
0 \\
0 \\
\text { CPD } 1 \\
0 \\
0 \\
\text { congenital } \\
\text { heart disease } 1\end{array}$ & $\begin{array}{r}28 \\
0 \\
1 \\
5 \\
2 \\
1 \\
4\end{array}$ \\
\hline
\end{tabular}

TABLE VIII

Time Needed for Correction of Foetal Bradycardja following Paracervical Block

\begin{tabular}{lcc}
\hline & Primiparae & Multiparae \\
\hline Time to correct bradycardia $>100 /$ min. & & \\
$0-15$ & 16 & 11 \\
$15-30$ & 1 & 2 \\
$>30$ & 0 & 0 \\
Time to correct bradycardia $<100 /$ min. & & \\
$0-15$ & 5 & 2 \\
$15-30$ & 0 & 0 \\
$>30$ & 0 & 0 \\
\hline
\end{tabular}


direct pressure on the foetal skull at the time of pelvic examination, ${ }^{31}$ alteration in vagal tone secondary to the block, ${ }^{32}$ or a transient high level of carbocaine in the foetus secondary to its rapid absorption directly following the blocks. ${ }^{33}$

\section{Summary and Conclusions}

A series of 377 patients who received one or more paracervical blocks with 1 per cent mepivicaine during the first stage of labour has been reviewed. The duration of action of the block in the 208 primiparae was 31 to 120 minutes in 85 per cent and over 120 minutes in 5 per cent. In 169 multiparae, 89 per cent lasted 31 to 120 minutes and 1 per cent over 120 minutes. The results were good in 81 per cent of primiparae and 76 per cent of the multiparae. There were failures in 3 per cent of primiparae and 5 per cent of multiparae.

In the 39 infants with low one-minute Apgar scores, none of the low scores could be related to the paracervical block. Transient post-block foetal bradycardia of below 100 was noted in four patients (1.6\%). This reaction, which has not been explained, did not represent foetal distress, but must be differentiated from it. There were no significant maternal or foetal complications secondary to paracervical block.

Despite the transient post-block decrease in uterine activity in 30 per cent of cases, there was no evidence that the paracervical block altered the length of labour or the rate of cervical dilation. Single-shot paracervical blocks proved to be a simple, safe, effective, easily taught, useful adjunct to achieving effective analgesia during the first stage of labour in uncomplicated pregnancies.

\section{RÉSUMÉ}

Les dossiers de 377 patients qui ont reçu un ou plusieurs blocages paracervicaux à la mépivicaine à 1 pour cent au cours du premier stage du travail ont été revus. La durée d'action du blocage chez les 208 primipares fut de 31 d 120 minutes dans 85 pour cent des cas et de plus de 120 minutes dans 5 pour cent des cas. Chez 169 multipares, 89 pour cent ont duré de 31 a 120 minutes et 1 pour cent plus de 120 minutes. Les résultats furent bons chez 81 pour cent des primipares et 76 pour cent des multipares. Il y a eu échec chez 3 pour cent des primipares et 5 pour cent des multipares.

Des 39 nouveaux nés à bas pointage d'après la table d'évaluation d'Apgar, aucun ne peut être associé au blocage paracervical. Une bradycardie foetale transitoire de moins de 100 fut observée chez 4 patients (1.6\%) après le blocage. Cette réaction qui ne fut pas expliquée ne signifiait pas de la détresse foetale, mais le diagnostic doit être fait. Il n'y eut pas de complication maternelle et foetale importante secondaire au blocage paracervical.

En dépit d'une activité utérine transitoire diminuée chez 30 pour cent des cas, le blocage paracervical ne semble pas avoir changé la durée du travail et le rhythme de la dilatation du col. Le blocage paracervical à dose unique s'avère donc une technique simple, sûre, facile à enseigner, et un atout utile pour obtenir une analgésie efficace au cours du premier stage du travail, dans les cas de grossesse normale. 


\section{REFERENCES}

1. Aldrmge, C. W., JR.; Nanzig, R. P.; \& BeAton, J. H. Uterosacral Block and the Anesthesia Problem. J. Obste. \& Gynec. 81: 941 (1961).

2. BAREeN, M. J., Jr.; FrEEEMAN, D. W.; \& BARNo, A. Transvaginal Regional Block Anesthesia in Labor. Surg. Gynec. \& Obst. 114: 375 (1962).

3. Coopre, K. \& Mom, J. C. Paracervical Nerve Block: A Simple Method of Pain Relief in Labour. Brit.M.J. 1: 1372 (1963).

4. Davts, J. E. et al. The Combined Paracervical-pudendal Block Anaesthesia for Labor and Delivery. Am. J. Obst. \& Gynec. 89: 336 (1964).

5. Freeman, D. W.; Bellevimle, T. P.; \& Barno, A. Paracervical Block Anesthesia in Labor. Obst. \& Gynec. 8: 270 (1956).

6. PAge, E. P.; KaM, M. L.; \& Chappetr, C. C. Usefulness of Paracervical Block in Obstetrics. Am. J. Obst. \& Gynec. $81: 1094$ (1961).

7. Seeds, A. E., JR.; Stenn-Messanger, P.; \& Dorsey, J. H. Paracervical Blocks: Results of a Double-blind Evaluation. Obst. \& Gynec. 20: 462 (1962).

8. Spanos, W. J. \& Steele, J. C. Uterosacral Block. Obst. \& Gynec. 13: 129 (1959).

9. White, C. A. \& Prrnn, R. M. Paracervical Block Anesthesia in Obstetrics. Postgrad. Med. 33: 585 (1963).

10. DenNI, K. J. Unilateral Parametritis following Paracervical Nerve Block. J. Obst. \& Gynaec. Brit. Common. 71: 797 (1964).

11. NyirJesy, I. et al. Hazards of the Use of Paracervical Block Anesthesia in Obstetrics. Am. J. Obst. \& Gynec. 87: 231 (1963).

12. Gellert, P. Aufhebung der Wehenschmerzen und Wehenüberdruck. Monatsschr. Geburstsch. Gynak. 73: 143 (1926).

13. HENRIET, J. Les Bases anatamo-physiologiques et technique sonelle de linfiltration du plexus peluiperineal. Strasbourg Med. 97: 622 (1937).

14. Prbram, E. Die schmerzlose Geburtsleitung in Lokalanästhesie. Klin. Wchnschr. 6: 1282 (1927).

15. RosenFeid, S. S. Paracervical Anesthesia for the Relief of Labor Pains. Am. J. Obst. \& Gynec. 50: 527 (1945).

16. Van Prangh, I. G. L. \& Povey, W. G. Paracervical Block Anesthesia in Labour. Canad. M.A.J. 94: 262 (1966).

17. Rem, D. E. A Textbook of Obstetrics. Philadelphia: Saunders (1962), p. 383

18. Davis, J. E. et al. Paracervical Block for Pain Relief in Labor. Obst. \& Gynec. 19: 195 (1962).

19. Gemmeli, A. A. Method of Demonstrating Ganglia of the Cervix Uteri. J. Obst. \& Gynaec. Brit. Emp. 33: 259 (1926).

20. Krantz, K. E. Innervation of the Human Uterus. Ann. New York Acad. Sc. 75: 770 (1959).

21. ReYNords, S. R. M. Physiology of the Uterus. 2nd ed., New York: Hafner (1965), p. 463.

22. Povex, W. G. A Simple Device for Paracervical and Pudendal Block. Obst. \& Gynec. 28: 435 (1966).

23. KobaK, A. J.; Sadove, M. S.; \& Mazeros, W. T. Paracervical Block: A Transvaginal Regional Pain Relief. Obst. \& Gynec. 19: 302 (1962).

24. Crans, L. A. \& Hendrucrs, C. H. Normal Labor in Vertex Presentation. Am. J. Obst. \& Gynec. 91: 385 (1965).

25. Eastman, N. J. \& Hetrman, L. M. Williams Obstetrics. 12th ed., New York: Appleton Century Crofts (1961), p. 427.

26. Zourlas, P. A. \& Kumar, D. An Objective Evaluation of Paracervical Block on Human Uterine Contractility. Am. J. Obst. \& Gynec., 91: 217 (1965).

27. Prrmon, R. M. \& Goddarm, W. B. Paracervical and Uterosacral Block in Obstetrics: A Controlled Double-blind Study. Obst. \& Gynec. 21: 737 (1963).

28. Caldeyro-Barcia, R. \& Posemo, J. J. The Physiology of the Uterine Contraction. Clin. Obst. \& Gynec. 3: 386 (1960).

29. Apgar, V. Proposal for a New Method of Evaluation of the Newborn Infant. Anesth. \& Analg. 32: 260 (1953).

30. Beard, R. W.; Morris, E. D.; \& Clayton, S. G. Foetal Blood Sampling in Clinical Obstetrics. J. Obst. \& Gynaec. Brit. Common. 73: 562 (1966).

31. HoN, E. H. The Diagnosis of Fetal Distress. Clin. Obst. \& Gynec. 3: 860 (1960).

32. ReYNolds, S. R. M. Regulation of Fetal Circulation: Its Relation to Fetal Distress. Clin. Obst. \& Gynec. 3: 834 (1960).

33. Poprers:. P. J. Personal communication. 